\title{
The immunosuppressive factors IL-10, TGF- $\beta$, and VEGF do not affect the antigen-presenting function of CD40-activated B cells
}

\author{
Alexander Shimabukuro-Vornhagen ${ }^{1 \dagger}$, Andreas Draube $^{1 \dagger}$, Tanja M Liebig $^{1}$, Achim Rothe $^{1}$, Matthias Kochanek $^{2}$ and
} Michael S von Bergwelt-Baildon ${ }^{1,3^{*}}$

\begin{abstract}
Background: Progress in recent years strengthened the concept of cellular tumor vaccinations. However, a crucial barrier to successful cancer immunotherapy is tumor-mediated immunosuppression. Tumor-derived soluble factors such as IL-10, TGF- $\beta$, and VEGF suppress effector cells either directly or indirectly by disruption of dendritic cell (DC) differentiation, migration and antigen presentation. Human B cells acquire potent immunostimulatory properties when activated via CD40 and have been shown to be an alternative source of antigen-presenting cells (APCs) for cellular cancer vaccines. Nevertheless, in contrast to DCs little knowledge exists about their susceptibility to tumor derived immunosuppressive factors. Thus, we assessed whether IL-10, TGF- $\beta$, or VEGF do affect key aspects of the immunostimulatory function of human CD40-activated B cells.
\end{abstract}

Methods: Cell surface expression of adhesion and costimulatory molecules and the proliferation capacity of CD40activated B cells were compared to untreated controls by flow cytometry. Migration towards important chemokines of secondary lymph organs was measured with or without exposure to the immunosuppressive cytokines. Finally, an influence on T cell stimulation was investigated by allogeneic mixed lymphocyte reactions. For statistical analysis Student's $t$ test or two-way analysis of variance followed by Bonferroni's post-hoc test was used to compare groups. $P$ values of $<0.05$ were considered statistically significant.

Results: Neither cell adhesion nor the expression of MHC class II and costimulatory molecules CD80 and CD86 was inhibited by addition of IL-10, TGF- $\beta$, or VEGF. Likewise, the proliferation of CD40-activated B cells was not impaired. Despite being exposed to IL-10, TGF- $\beta$, or VEGF the $B$ cells migrated equally well as untreated controls to the chemokines SLC and SDF-1a. Most importantly, the capacity of CD40-activated B cells to stimulate CD4 ${ }^{+}$and CD8 ${ }^{+}$ $T$ cells remained unaffected.

Conclusion: Our findings suggest that key immunostimulatory functions of CD40-activated B cells are resistant to inhibition by the immunosuppressive factors IL-10, TGF- $\beta$, and VEGF. This supports considerations to use ex vivo generated CD40-activated B cells as a promising alternative or additional APC for cellular immunotherapy, especially in settings where these immunosuppressive cytokines are present in tumor environment.

Keywords: CD40-activated B cells, Antigen-presenting cells, IL10, TGF- $\beta$, VEGF, Tumor immunotherapy

\footnotetext{
* Correspondence: michael.bergwelt@uk-koeln.de

${ }^{\dagger}$ Equal contributors

${ }^{1}$ Cologne Interventional Immunology (CII), University Hospital of Cologne,

Cologne, Germany

${ }^{3}$ Cologne Interventional Immunology (CII), Department I of Internal Medicine,

University Hospital of Cologne, Kerpener Str. 62, 50924, Cologne, Germany

Full list of author information is available at the end of the article
} 


\section{Background}

The immune system plays an important role in the control of tumor development and progression. Thus, since decades immunotherapeutic strategies aim to exploit the ability of the immune system to detect and destroy tumor cells. One of the most promising concepts is the use of antigen-presenting cells (APCs) as cellular adjuvants for tumor vaccination. Especially, dendritic cells (DCs) have been identified as the ideal APC source due to their natural antigen-processing and presenting functions, their migratority capacities and the ability to activate naïve $\mathrm{T}$ cells [1]. However, a general barrier to successful cancer immunotherapy is the tumor-induced immunosuppression which is mainly mediated by tumorderived soluble factors in the tumor microenvironment $[2,3]$. This is also true for APC-based tumor vaccinations strategies [4].

Among the most well-known and best characterized tumor-derived immunosuppressive molecules are interleukin-10 (IL-10) [5,6], transforming growth factor-beta (TGF- $\beta$ ) $[7,8]$, and vascular endothelial growth factor (VEGF) $[9,10]$. An important mechanism by which IL10 , TGF- $\beta$, and VEGF counteract the development of an anti-tumor immune response is through inhibition of DC differentiation, maturation, trafficking, and antigen presentation $[6,11]$.

In recent years the antigen-presenting function of $B$ lymphocytes has gained increasing attention. Accumulating evidence demonstrates that B cells serve many functions in the immune response beside antibody mediated mechanisms [12]. Cytokine production and antigen-presentation are important mechanisms by which B lymphocytes contribute to both to immunity and immune pathology [13-16]. Activated antigen-presenting B cells have been shown to efficiently induce both $\mathrm{CD}_{4}^{+}$and $\mathrm{CD}^{+} \mathrm{T}$ cells responses in vitro and in vivo [17-20]. Therefore, many research groups are currently evaluating $B$ cell-based vaccines as an alternative to DC-based vaccines for cancer immunotherapy [18,19,21-27].

CD40-activated B cells can be prepared at relatively low costs as a highly pure homogenous population that can be expanded from small amount of peripheral blood even from cancer patients [28]. However, it is not known whether tumor-derived immunosuppressive factors affect the antigen-presenting capacity of CD40-activated B cells in a similar fashion as in DC. We therefore studied the effect of IL-10, TGF- $\beta$, and VEGF on the phenotype, migratory ability, and T cell stimulatory capacity of CD40activated $\mathrm{B}$ cells in vitro.

\section{Methods}

\section{Flow cytometry}

Immunophenotypic analysis was performed using fluorescence-activated cell sorting (FACS) according to standard protocols. The cells were analyzed on a FACSCanto flow cytometer (BD Biosciences, Heidelberg, Germany). Antibodies against CD19, CD80, CD86, HLA-DR, CD3, and CD25 were purchased from BD Pharmingen (Heidelberg, Germany).

\section{Generation of CD40-activated B cells and cell culture}

CD40-B cells were generated as described previously [29]. In brief, whole PBMC were cultured on irradiated NIH3T3 fibroblasts transfected with human CD40 ligand (tCD40L) in the presence of recombinant human interleukin-4 (2 ng/ml; R\&D Systems, Minneapolis, MN, USA) and clinical-grade cyclosporin A (CsA, $5.5 \times 10^{-7} \mathrm{M}$; Novartis, Basel, Switzerland) in Iscove's modified Dulbecco's medium (IMEM; Invitrogen, Karlsruhe, Germany) supplemented with $10 \%$ pooled human serum. The expanding cells were transferred onto freshly prepared tCD40L cells and fed with cytokine-replenished medium without CsA every 3-4 days. After 2-3 weeks in culture the CD40-activated B cells had a purity of $>95 \%$ and were used for the experiments. Therefore they were cultured for 4 days in the presence of $40 \mathrm{ng} / \mathrm{ml} \mathrm{IL-10,} 10 \mathrm{ng} / \mathrm{ml}$ TGF- $\beta, 20 \mathrm{ng} / \mathrm{ml}$ VEGF or vehicle as a control. For these concentrations the inhibitory effects on APC functions of DCs have been demonstrated previously [11]. Prior to use the activity of IL-10, TGF- $\beta$, and VEGF at the given concentrations was tested by assessing their inhibitory effect on DC maturation and for IL-10 and TGF- $\beta$ additionally on T cell proliferation.

\section{In vitro migration assay}

To assess B cell migration, $5 \times 10^{5}$ CD40-B cells were transferred into the upper chamber of $5-\mu \mathrm{m}$ pore size transwell plates (Costar, Cambridge, MA, USA). Varying amounts of the chemokines SDF- $1 \alpha$ and SLC (R\&D Systems) were added to the lower chamber. After 2 hours at $37^{\circ} \mathrm{C}$, the number of cells that had migrated into the lower chamber was determined using a hemacytometer.

\section{T cell proliferation assay}

Untouched $\mathrm{CD}^{+} \mathrm{T}$ cells and $\mathrm{CD}^{+} \mathrm{T}$ cells were obtained from buffy coats by negative selection using Rosette Sep ${ }^{\circledR}$ (StemCell Technologies) human $\mathrm{CD}^{+}$and $\mathrm{CD}^{+} \mathrm{T}$ cell enrichment cocktails according manufacturers' instructions. Prior to allogeneic mixed lymphocyte reactions (MLR) the $\mathrm{CD}^{+}$and $\mathrm{CD}^{+} \mathrm{T}$ cells were labeled with carboxyfluorescein diacetate succinimidyl ester (CFSE, Molecular Probes) according to standard protocols. A total of $1 \times 10^{5}$ CFSE-labeled $\mathrm{CD}^{+}$or $\mathrm{CD}^{+} \mathrm{T}$ cells were co-incubated with allogeneic CD40-B cells as stimulators at different $B$ to T cell ratios ranging from 1:1 to 1:20. After 5-7 days proliferation was assessed by flow cytometry. 


\section{Statistical analysis}

Data are reported as means \pm standard deviation unless stated otherwise. Student's $t$ test or, where appropriate, two-way analysis of variance followed by Bonferroni's post-hoc test was used to compare groups. $P$ values of $<0.05$ were considered statistically significant.

\section{Results}

Phenotype of CD40-activated B cells

Upon activation via CD40 B cells upregulate the expression of MHC class II, costimulatory molecules, and adhesion molecules and as a consequence they acquire potent T-cell stimulatory activity. We therefore first studied the effect of IL-10, TGF- $\beta$, and VEGF on the morphology and cell surface expression of HLA-DR and costimulatory molecules of CD40-activated B cells. The upregulation of adhesion molecules such as ICAM-1 results in the formation of round clusters through homotypic adhesion of activated B cells. As shown in Figure 1 IL-10, TGF- $\beta$, and VEGF had no impact on cluster formation of CD40-activated B cells.

For the same activation protocol used in this work we have repeatedly shown a strong upregulation of CD80, CD86 and HLA-DR both for B cells of healthy donors and of cancer patients [28,29]. Thus, we used the expression levels of vehicle treated CD40-activated B-cells as baselines and these were compared to the expression levels of cells exposed to the immunosuppressive cytokines. In a series of experiments no statistically significant differences between CD40-activated B cells treated with IL-10, TGF- $\beta$, or VEGF in comparison to controls were observed (Figure 2).

\section{Proliferation of CD40-activated B cells}

Activation via CD40 induces proliferation of B cells. We assessed whether the proliferation was inhibited by any of the three immunosuppressive factors. Table 1

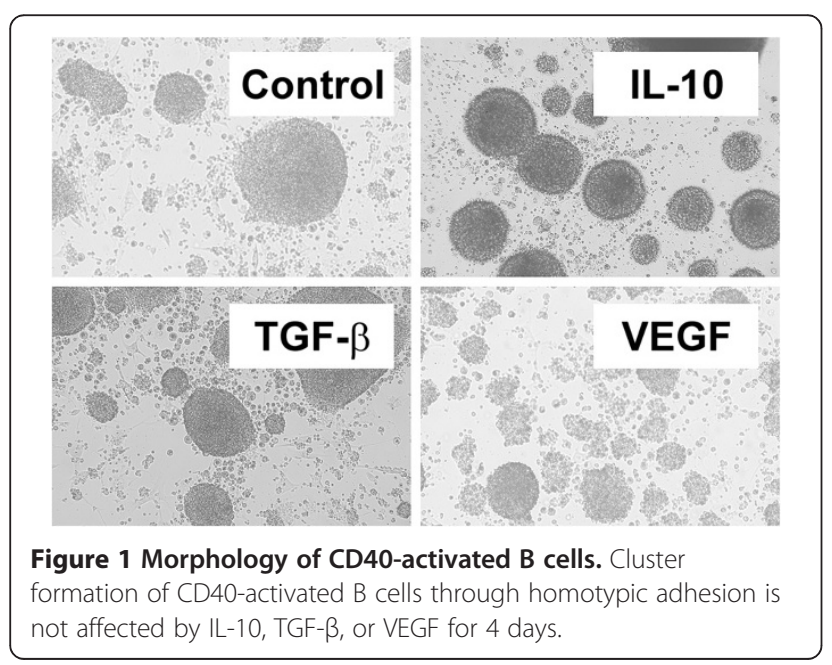

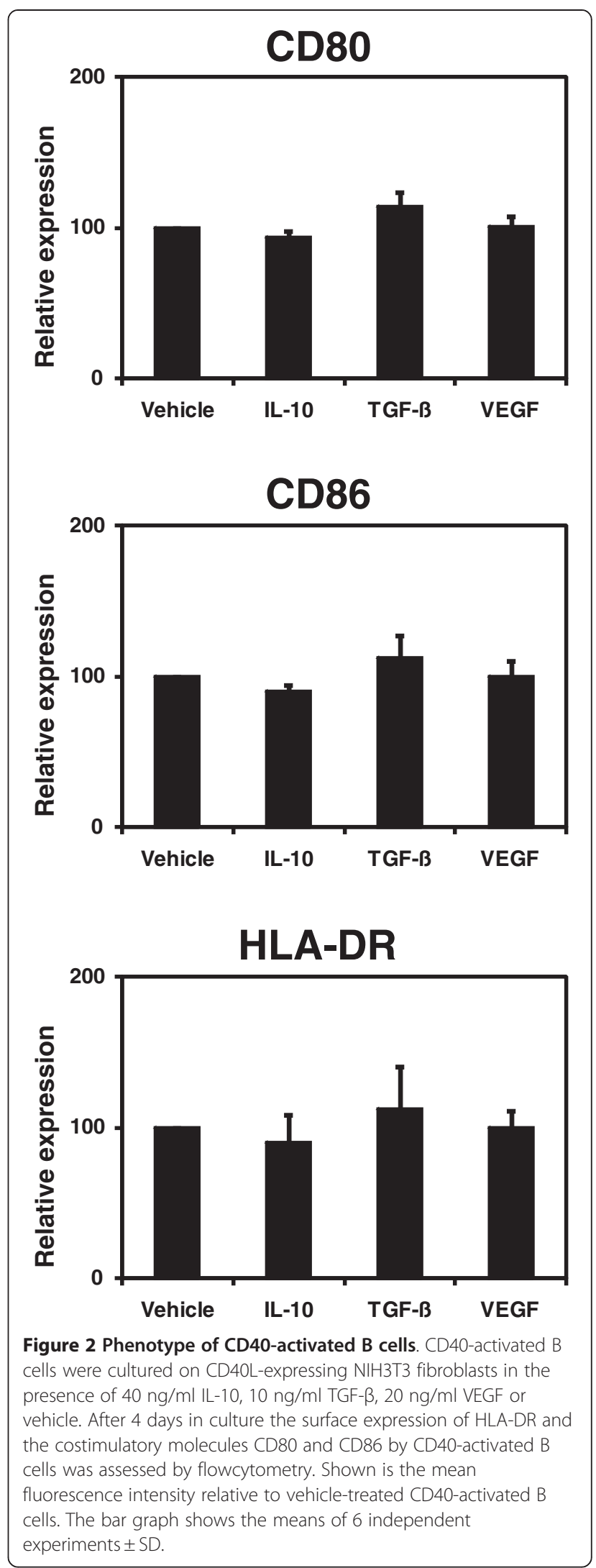


Table 1 Proliferation of CD40-activated B cells

\begin{tabular}{llll}
\hline & Mean (\%) & SD & $\mathrm{p}$ \\
\hline Control & 197 & $+/-52$ & - \\
\hline IL-10 & 301 & $+/-106$ & $<0.01$ \\
\hline TGF- $\beta$ & 222 & $+/-95$ & Not significant \\
\hline VEGF & 197 & $+/-70$ & Not significant \\
\hline
\end{tabular}

Means of the relative increase in cell number of 8 experiments.

summarizes the results of the proliferation of CD40activated B cells cultured in the presence of either IL-10, TGF- $\beta$, or VEGF. After four days the cells were removed from the wells and the proliferation was determined by counting. TGF- $\beta$ and VEGF exerted no effect on the proliferation of B cells activated through CD40. Consistent with previous reports we found that IL-10 enhanced the expansion of CD40-activated B cells [30].

\section{Migratory ability}

Migration of APCs to the secondary lymphoid organs is essential for the induction of $\mathrm{CD}^{+}$and $\mathrm{CD} 8^{+} \mathrm{T}$ cell responses. For CD40-activated $\mathrm{B}$ cells of healthy donors and of cancer patients the migration capacity has been shown $[28,31]$. We thus studied the influence of IL-10, TGF- $\beta$, and VEGF on the migratory ability of CD40activated $\mathrm{B}$ cells towards the important lymph node homing cytokines SDF- $1 \alpha$ and SLC in vitro. We used the migration of vehicle treated CD40-activated B cells as controls (relative migration $=1$ ). The $\mathrm{T}$ cell migration of CD40-activated B cells treated with IL-10, TGF- $\beta$, or VEGF in comparison to these controls are shown in Figure 3. CD40-activated B cells migrated equally well towards SDF-1 $\alpha$ and SLC independent of whether they were treated with vehicle, IL-10, TGF- $\beta$, or VEGF.

\section{T cell stimulation by CD40-activated B cells}

In order to assess the impact of tumor-derived immunosuppressive factors on the T cell-stimulatory capacity of CD40-activated B cells we compared the ability of CD40-activated B cells which were treated with IL-10, TGF- $\beta$, or VEGF to induce the proliferation of CFSElabeled $\mathrm{CD}^{+}$or $\mathrm{CD}^{+} \mathrm{T}$ lymphocytes from healthy HLA-mismatched donors. Figure 4 shows the result of the CFSE-proliferation assays comparing vehicle controls with CD40-activated B cells which were exposed to IL-10, TGF- $\beta$, or VEGF. We did not observe statistically significant differences in the proliferation of $\mathrm{CD}_{4}^{+}$or $\mathrm{CD}^{+} \mathrm{T}$ cells between the controls and CD40-activated B cells which were cultured in the presence of $40 \mathrm{ng} / \mathrm{ml} \mathrm{IL-10,} 10 \mathrm{ng} / \mathrm{ml} \mathrm{TGF-} \beta$, or $20 \mathrm{ng} / \mathrm{ml}$ VEGF. Therefore, neither IL-10, TGF- $\beta$, nor VEGF was able to inhibit the capacity CD40-activated $\mathrm{B}$ cell to activate $\mathrm{CD} 4^{+}$or $\mathrm{CD} 8^{+} \mathrm{T}$ lymphocytes.

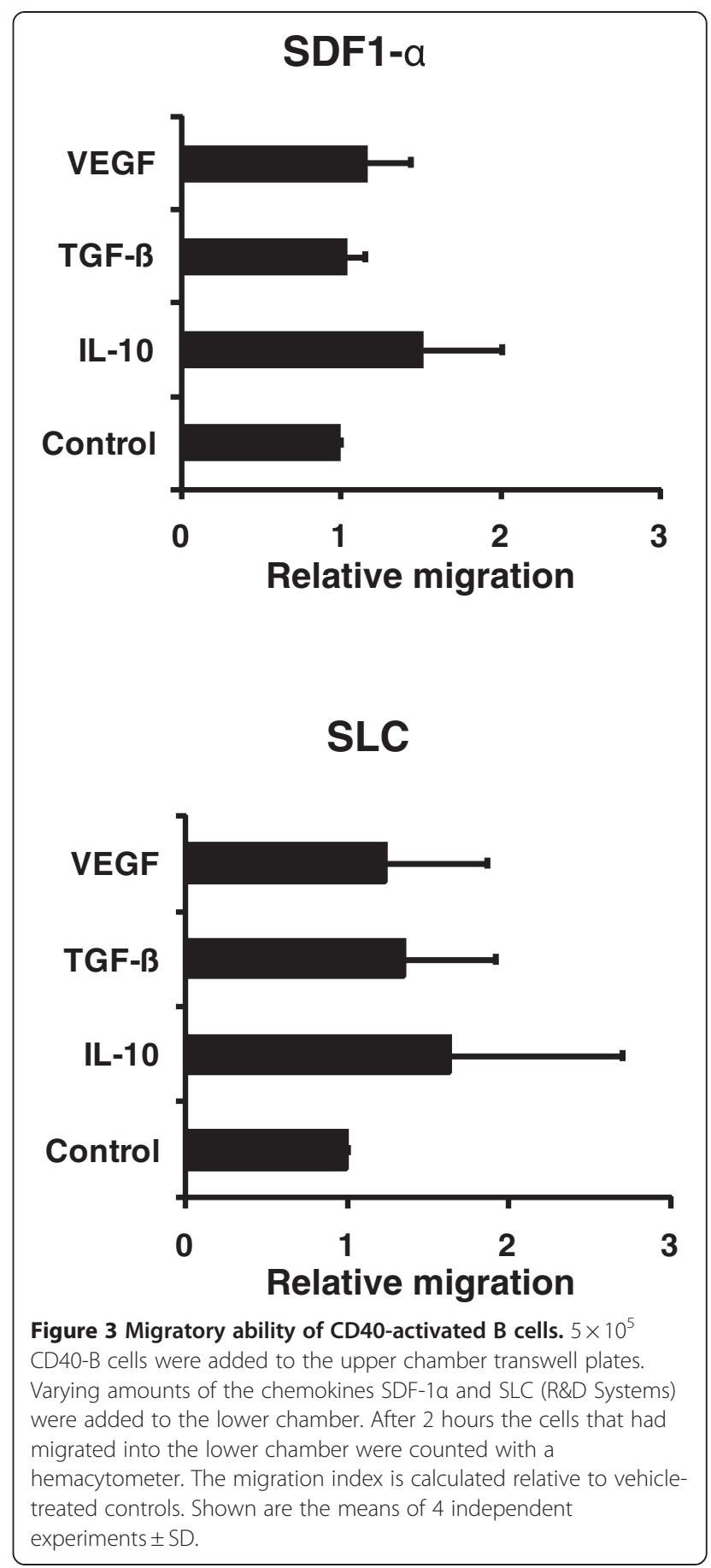

\section{Discussion}

Due to a growing body of knowledge about immunosurveillance - and loss thereof - anti-tumor immunotherapy has been refined [32]. Nevertheless, especially results of APC-based tumor vaccination trials often have often not met the high expectations. Lack of efficacy mainly originates from well-defined tumor escape mechanisms $[2,3,33]$. Tolerizing conditions of the tumor 


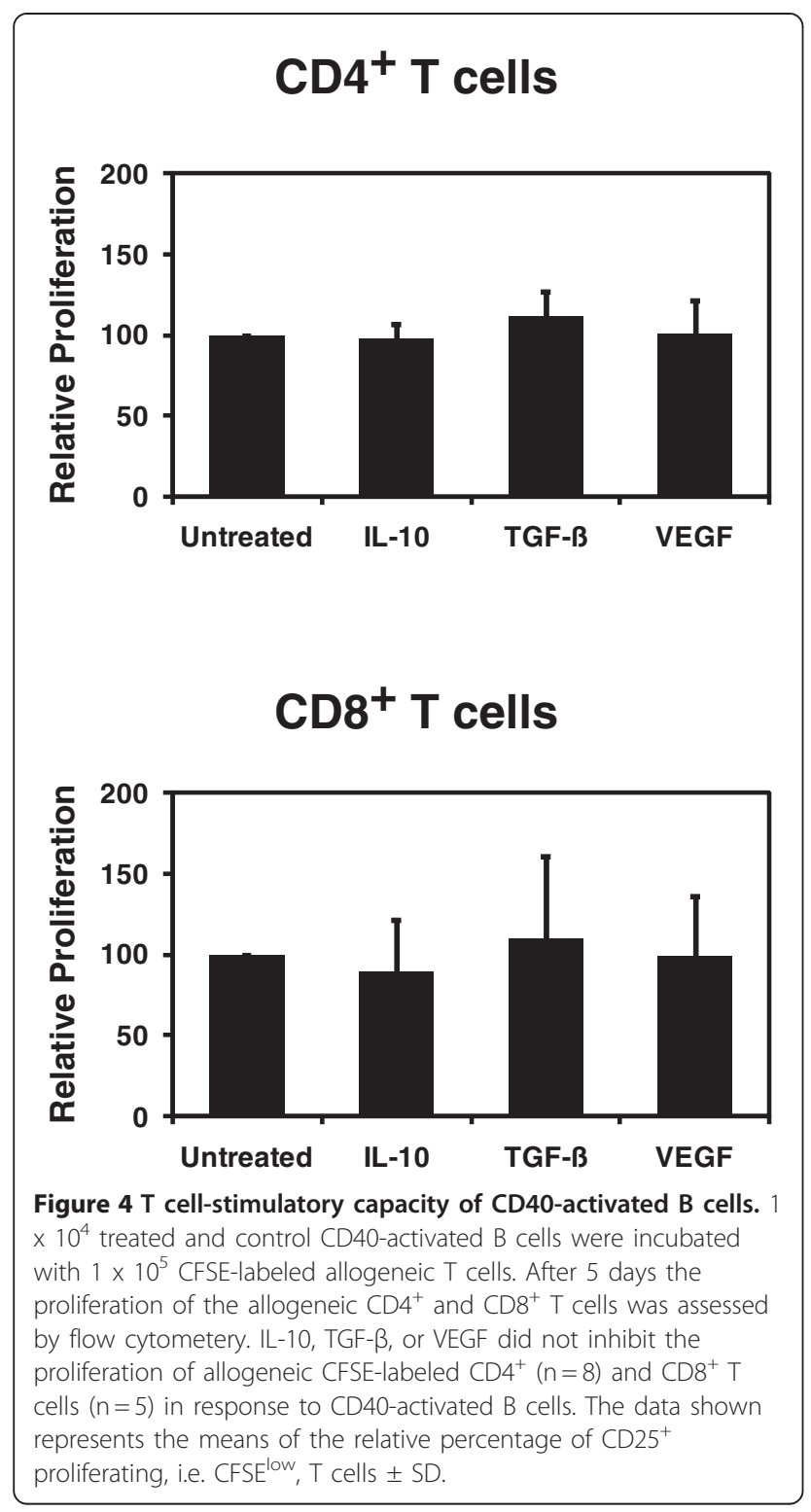

environment are mainly driven by tumor or bystander cell derived cytokines inducing tolerogenic DC, e.g. by triggering myeloid DC B7-H1 expression [34], and by recruitment of regulatory $\mathrm{T}$ cells [35], myeloid-derived suppressor cells (MDSCs) and mesenchymal stroma cells (MSCs) [36]. IL-10, TGF- $\beta$, and VEGF all have been identified as key factors that mediate the inhibitory action of the tumor microenvironment. Their serum levels are frequently increased in cancer patients and the tumor tissues of many cancer types are enriched for these immunosuppressive factors [37-39]. The main activity of IL-10 is related to downregulation of $\mathrm{T}$ cell function, which occurs predominantly through indirect mechanisms involving APCs [40]. IL-10 has been shown to impair antigen-presentation by DCs through reduction of the cell surface expression of adhesion and costimulatory molecules as well as MHC class II. Furthermore, IL-10 promotes DC apoptosis and inhibits DC migration to the secondary lymphoid organs [41,42]. DCs isolated from transgenic mice that over-express IL-10 have a defect in antigen presentation and decreased capacity to induce $\mathrm{T}$ cell activation. Conversely, in IL-10-deficient tumor-bearing mice the defect in DC function was reversed [43]. As a consequence IL-10-conditioned DCs are tolerogenic and induce $T$ cell anergy [6,44]. Like IL-10 TGF- $\beta$ prevents the trafficking of DCs to the lymph nodes [45]. In addition, TGF- $\beta$ impairs the maturation of DCs and thereby leads to the accumulation of immature DCs with the ability to generate regulatory $\mathrm{T}$ cells $[8,46]$. VEGF also inhibits $\mathrm{DC}$ maturation leading to an accumulation of immature DCs with impaired APC function within the tumor microenvironment and the tumor-draining lymph nodes [9]. Consequently, inhibition of TGF- $\beta$, IL-10, or VEGF signaling improves DC function and enhances the efficacy of tumor vaccines [47-49]. Another strategy to address these tumor escape mechanisms in cellular tumor vaccinations is the use of alternative APC sources. In this context human CD40-activated B cells have gained increasing interest.

We and others have previously shown that CD40-activated $B$ cells are equipped with a profile of chemokine receptors that are required for the homing to the secondary lymphoid organs [31]. Furthermore, CD40-activated B cells are potent antigen-presenting cells and are able to prime both $\mathrm{CD} 4^{+}$and $\mathrm{CD}^{+} \mathrm{T}$ cells in vitro. The capacity of CD40-activated B cell-based cancer vaccine to induce $\mathrm{CD} 4^{+}$ and $\mathrm{CD} 8^{+} \mathrm{T}$ cell responses also has been shown in vivo in mice and a large animal model in dogs [22,25,27,50,51]. An important advantage of CD40-activated B cells is that they can be highly expanded at relatively low cost from small amounts of peripheral blood even from cancer patients $[21,28]$. Nevertheless, it has also has been proposed that their APC functions have to be further evaluated in more detail before they are used in therapeutic vaccinations [52].

It is known that IL-10, TGF- $\beta$, and VEGF play important roles in the regulation of B cells. TGF- $\beta$ specifically induces the class switch to IgA while IL-10 promotes switching to IgA, IgG, and IgE [53]. TGF- $\beta$ furthermore induces apoptosis in resting $B$ cells and inhibits B cell proliferation [54]. VEGF leads to the accumulation of B cells in the spleen [55]. However, compared to DCs the influence of these immunosuppressive cytokines on $\mathrm{CD} 40$-activated $\mathrm{B}$ cells is poorly characterized. We therefore studied the effects of IL-10, TGF- $\beta$, and VEGF on crucial steps in the generation of a $\mathrm{T}$ cell-mediated immune response in vitro. Neither TGF- $\beta$ nor VEGF had a significant effect on B cell proliferation. Exposure to IL-10 on the other hand increased the expansion of $B$ lymphocytes. The migratory ability of B cells remained unchanged after exposure to all the three immunosuppressive factors. Even though it was 
previously reported that IL-10 impairs the motility of murine and human B cells [56] the activation by CD40 seems to protect B cells from the inhibitory effect of IL-10. For TGF- $\beta$ our findings supports assumptions from previous reports that some of the immunosuppressive effects on $B$ cells can be blocked by CD40 signaling $[57,58]$. Thus, with the notable exception of the enhancing effect of IL-10 on $B$ cell proliferation important APC functions of CD40activated B cells are not affected by IL-10, TGF- $\beta$, or VEGF.

\section{Conclusion}

In summary, our results show that at least in vitro the APC function of CD40-activated B cells is highly resistant to inhibition by the immunosuppressive factors IL10 , TGF- $\beta$, and VEGF, which have been shown to play an important role in the immunosuppressive microenvironment of many tumors and to interfere with the differentiation and APC function of DCs. Thus, ex vivo generated CD40-activated B cells are well suited as APCs for cellular vaccines. They represent a promising alternative or additional APC for cellular immunotherapy, especially in settings where the above cytokines are present in the tumor microenvironment.

\section{Competing interests}

The authors declare that they have no competing interests.

\section{Acknowledgments}

We would like to thank Anne Fiedler for expert technical assistance. This work was supported by a Max-Eder Junior Research Grant from the Deutsche Krebshilfe. M. v. B.-B. was supported by the Else Kröner-FreseniusStiftung (P68/08//A50/08).

\section{Author details \\ 'Cologne Interventional Immunology (CII), University Hospital of Cologne, Cologne, Germany. ${ }^{2}$ Critical Care Unit, Department I of Internal Medicine, University Hospital of Cologne, Cologne, Germany. ${ }^{3}$ Cologne Interventional Immunology (CII), Department I of Internal Medicine, University Hospital of Cologne, Kerpener Str. 62, 50924, Cologne, Germany.}

\section{Authors' contributions \\ ASV and AD made substantial contributions to conception and design as well as to the interpretation of the data and drafted the manuscript. TML and ASV carried out the experiments. TML, AR and MK contributed to conception, the interpretation of the data and assisted to draft the manuscript. MBB conceived of the study, participated in its design and coordination and helped to draft the manuscript. All authors read and approved the final manuscript.}

Received: 10 April 2012 Accepted: 16 May 2012

Published: 16 May 2012

\section{References}

1. Hett EJ, Prestwich RJ, Melcher AA: The evolving role of dendritic cells in cancer therapy. Expert Opin Biol Ther 2010, 10:369-379.

2. Du C, Wang Y: The immunoregulatory mechanisms of carcinoma for its survival and development. J Exp Clin Cancer Res 2011, 30:12.

3. Zou W: Regulatory T cells, tumour immunity and immunotherapy. Nat Rev Immunol 2006, 6:295-307.

4. Huang FP, Chen YX, To CK: Guiding the "misguided" - functional conditioning of dendritic cells for the DC-based immunotherapy against tumours. Eur J Immunol 2011, 41:18-25.
5. Sabat R, Grutz G, Warszawska K, Kirsch S, Witte E, Wolk K, Geginat J: Biology of interleukin-10. Cytokine Growth Factor Rev 2010, 21:331-344.

6. Steinbrink K, Jonuleit H, Muller G, Schuler G, Knop J, Enk AH: Interleukin-10treated human dendritic cells induce a melanoma-antigen-specific anergy in CD8(+) T cells resulting in a failure to lyse tumor cells. Blood 1999, 93:1634-1642.

7. Yang L: TGFbeta, a potent regulator of tumor microenvironment and host immune response, implication for therapy. Curr Mol Med 2010, 10:374-380.

8. Geissmann F, Revy P, Regnault A, Lepelletier Y, Dy M, Brousse N, Amigorena S, Hermine O, Durandy A: TGF-beta 1 prevents the noncognate maturation of human dendritic Langerhans cells. J Immunol 1999, 162:4567-4575.

9. Johnson BF, Clay TM, Hobeika AC, Lyerly HK, Morse MA: Vascular endothelial growth factor and immunosuppression in cancer: current knowledge and potential for new therapy. Expert Opin Biol Ther 2007, 7:449-460.

10. Gabrilovich DI, Chen HL, Girgis KR, Cunningham HT, Meny GM, Nadaf S, Kavanaugh D, Carbone DP: Production of vascular endothelial growth factor by human tumors inhibits the functional maturation of dendritic cells. Nat Med 1996, 2:1096-1103.

11. Gabrilovich D: Mechanisms and functional significance of tumourinduced dendritic-cell defects. Nat Rev Immunol 2004, 4:941-952.

12. Martin $F$, Chan AC: B cell immunobiology in disease: evolving concepts from the clinic. Annu Rev Immunol 2006, 24:467-496.

13. Chan OT, Hannum LG, Haberman AM, Madaio MP, Shlomchik MJ: A novel mouse with $B$ cells but lacking serum antibody reveals an antibodyindependent role for B cells in murine lupus. J Exp Med 1999, 189:1639-1648.

14. Kleindienst $P$, Brocker $T$ : Concerted antigen presentation by dendritic cells and B cells is necessary for optimal CD4 T-cell immunity in vivo. Immunology 2005, 115:556-564.

15. Yan J, Harvey BP, Gee RJ, Shlomchik MJ, Mamula MJ: B cells drive early T cell autoimmunity in vivo prior to dendritic cell-mediated autoantigen presentation. J Immunol 2006, 177:4481-4487.

16. Shimabukuro-Vornhagen A, Hallek MJ, Storb RF, von Bergwelt-Baildon MS: The role of $B$ cells in the pathogenesis of graft-versus-host disease. Blood 2009, 114:4919-4927.

17. Constant S, Schweitzer N, West J, Ranney P, Bottomly K: B lymphocytes can be competent antigen-presenting cells for priming CD4+ T cells to protein antigens in vivo. J Immunol 1995, 155:3734-3741.

18. Kondo E, Topp MS, Kiem HP, Obata Y, Morishima Y, Kuzushima K, Tanimoto M, Harada M, Takahashi T, Akatsuka Y: Efficient generation of antigenspecific cytotoxic T cells using retrovirally transduced CD40-activated B cells. J Immunol 2002, 169:2164-2171.

19. Fujiwara H, Melenhorst JJ, El Ouriaghli F, Kajigaya S, Grube M, Sconocchia G, Rezvani K, Price DA, Hensel NF, Douek DC, Barrett AJ: In vitro induction of myeloid leukemia-specific CD4 and CD8 T cells by CD40 ligand-activated $B$ cells gene modified to express primary granule proteins. Clin Cancer Res 2005, 11:4495-4503.

20. von Bergwelt-Baildon MS, Vonderheide RH, Maecker B, Hirano N, Anderson KS, Butler MO, Xia Z, Zeng WY, Wucherpfennig KW, Nadler LM, Schultze JL: Human primary and memory cytotoxic $\mathrm{T}$ lymphocyte responses are efficiently induced by means of CD40-activated B cells as antigenpresenting cells: potential for clinical application. Blood 2002, 99:3319-3325.

21. Coughlin CM, Vance BA, Grupp SA, Vonderheide RH: RNA-transfected CD40-activated $B$ cells induce functional T-cell responses against viral and tumor antigen targets: implications for pediatric immunotherapy. Blood 2004, 103:2046-2054.

22. Guo S, Xu J, Denning W, Hel Z: Induction of protective cytotoxic T-cell responses by a B-cell-based cellular vaccine requires stable expression of antigen. Gene Ther 2009, 16:1300-1313.

23. Kim SK, Nquyen Pham TN, Nguyen Hoang TM, Kang HK, Jin CJ, Nam $\mathrm{JH}$, Chung SY, Choi SJ, Yang DH, Kim YK, et al: Induction of myelomaspecific cytotoxic T lymphocytes ex vivo by CD40-activated B cells loaded with myeloma tumor antigens. Ann Hematol 2009, 88:1113-1123.

24. Lee J, Dollins CM, Boczkowski D, Sullenger BA, Nair S: Activated B cells modified by electroporation of multiple mRNAs encoding immune stimulatory molecules are comparable to mature dendritic cells in 
inducing in vitro antigen-specific T-cell responses. Immunology 2008, 125:229-240.

25. Mason NJ, Coughlin CM, Overley B, Cohen JN, Mitchell EL, Colligon TA, Clifford CA, Zurbriggen A, Sorenmo KU, Vonderheide RH: RNA-loaded CD40-activated B cells stimulate antigen-specific T-cell responses in dogs with spontaneous lymphoma. Gene Ther 2008, 15:955-965.

26. Shen SN, Xu Z, Qian XP, Ding YT, Yu LX, Liu BR: RNA-electroporated CD40activated $B$ cells induce functional T-cell responses against HepG2 cells. Eur J Cancer Care (Engl) 2008, 17:404-411.

27. Sorenmo KU, Krick E, Coughlin CM, Overley B, Gregor TP, Vonderheide RH, Mason NJ: CD40-activated B cell cancer vaccine improves second clinical remission and survival in privately owned dogs with non-Hodgkin's lymphoma. PLoS One 2011, 6:e24167.

28. Kondo E, Gryschok L, Klein-Gonzalez N, Rademacher S, Weihrauch MR, Liebig T, Shimabukuro-Vornhagen A, Kochanek M, Draube A, von Bergwelt-Baildon MS: CD40-activated B cells can be generated in high number and purity in cancer patients: analysis of immunogenicity and homing potential. Clin Exp Immunol 2009, 155:249-256.

29. Liebig TM, Fiedler A, Zoghi S, Shimabukuro-Vornhagen A, von BergweltBaildon MS: Generation of human CD40-activated B cells. J Vis Exp 2009, 32: doi:10.3791/1373. pii:1373.

30. Rousset F, Garcia E, Defrance T, Peronne C, Vezzio N, Hsu DH, Kastelein R Moore KW, Banchereau J: Interleukin 10 is a potent growth and differentiation factor for activated human B lymphocytes. Proc Natl Acad Sci U S A 1992, 89:1890-1893.

31. von Bergwelt-Baildon M, Shimabukuro-Vornhagen A, Popov A, KleinGonzalez N, Fiore F, Debey S, Draube A, Maecker B, Menezes I, Nadler LM, Schultze JL: CD40-activated B cells express full lymph node homing triad and induce T-cell chemotaxis: potential as cellular adjuvants. Blood 2006, 107:2786-2789.

32. Finn OJ: Cancer immunology. N Engl J Med 2008, 358:2704-2715

33. Steinman RM, Hawiger D, Nussenzweig MC: Tolerogenic dendritic cells. Annu Rev Immunol 2003, 21:685-711.

34. Curiel TJ, Wei S, Dong H, Alvarez X, Cheng P, Mottram P, Krzysiek R, Knutson KL, Daniel B, Zimmermann MC, et al: Blockade of B7-H1 improves myeloid dendritic cell-mediated antitumor immunity. Nat Med 2003, 9:562-567.

35. Gross $\mathrm{S}$, Walden $\mathrm{P}:$ Immunosuppressive mechanisms in human tumors: why we still cannot cure cancer. Immunol Lett 2008, 116:7-14.

36. Bianchi G, Borgonovo G, Pistoia V, Raffaghello L: Immunosuppressive cells and tumour microenvironment: focus on mesenchymal stem cells and myeloid derived suppressor cells. Histol Histopathol 2011, 26:941-951.

37. O'Hara RJ, Greenman J, MacDonald AW, Gaskell KM, Topping KP, Duthie GS, Kerin MJ, Lee PW, Monson JR: Advanced colorectal cancer is associated with impaired interleukin 12 and enhanced interleukin 10 production. Clin Cancer Res 1998, 4:1943-1948.

38. Shim KS, Kim KH, Han WS, Park EB: Elevated serum levels of transforming growth factor-beta1 in patients with colorectal carcinoma: its association with tumor progression and its significant decrease after curative surgical resection. Cancer 1999, 85:554-561.

39. Toi M, Kondo S, Suzuki H, Yamamoto Y, Inada K, Imazawa T, Taniguchi T, Tominaga T: Quantitative analysis of vascular endothelial growth factor in primary breast cancer. Cancer 1996, 77:1101-1106.

40. Sato T, Terai M, Tamura Y, Alexeev V, Mastrangelo MJ, Selvan SR: Interleukin 10 in the tumor microenvironment: a target for anticancer immunotherapy. Immunol Res 2011, 51:170-182.

41. Demangel C, Bertolino P, Britton WJ: Autocrine IL-10 impairs dendritic cell (DC)-derived immune responses to mycobacterial infection by suppressing DC trafficking to draining lymph nodes and local IL-12 production. Eur J Immunol 2002, 32:994-1002.

42. Ludewig B, Graf D, Gelderblom HR, Becker Y, Kroczek RA, Pauli G: Spontaneous apoptosis of dendritic cells is efficiently inhibited by TRAP (CD40-ligand) and TNF-alpha, but strongly enhanced by interleukin-10. Eur J Immunol 1995, 25:1943-1950.

43. Yang AS, Lattime EC: Tumor-induced interleukin 10 suppresses the ability of splenic dendritic cells to stimulate CD4 and CD8 T-cell responses. Cancer Res 2003, 63:2150-2157.

44. Steinbrink K, Graulich E, Kubsch S, Knop J, Enk AH: CD4(+) and CD8(+) anergic $T$ cells induced by interleukin-10-treated human dendritic cells display antigen-specific suppressor activity. Blood 2002, 99:2468-2476.
45. Sato K, Kawasaki H, Nagayama H, Enomoto M, Morimoto C, Tadokoro K, Juji T, Takahashi TA: TGF-beta 1 reciprocally controls chemotaxis of human peripheral blood monocyte-derived dendritic cells via chemokine receptors. J Immunol 2000, 164:2285-2295.

46. Roncarolo MG, Levings MK, Traversari C: Differentiation of T regulatory cells by immature dendritic cells. J Exp Med 2001, 193:F5-F9.

47. Terabe M, Ambrosino E, Takaku S, O'Konek JJ, Venzon D, Lonning S, McPherson JM, Berzofsky JA: Synergistic enhancement of CD8+ T cellmediated tumor vaccine efficacy by an anti-transforming growth factorbeta monoclonal antibody. Clin Cancer Res 2009, 15:6560-6569.

48. Vicari AP, Chiodoni C, Vaure C, Ait-Yahia S, Dercamp C, Matsos F, Reynard O, Taverne C, Merle P, Colombo MP, et al: Reversal of tumor-induced dendritic cell paralysis by CpG immunostimulatory oligonucleotide and anti-interleukin 10 receptor antibody. J Exp Med 2002, 196:541-549.

49. Gabrilovich DI, Ishida T, Nadaf S, Ohm JE, Carbone DP: Antibodies to vascular endothelial growth factor enhance the efficacy of cancer immunotherapy by improving endogenous dendritic cell function. Clin Cancer Res 1999, 5:2963-2970.

50. Park MY, Kim HS, Woo SJ, Kim CH, Park JS, Sohn HJ, Kim HJ, Oh ST, Kim TG: Efficient antitumor immunity in a murine colorectal cancer model induced by CEA RNA-electroporated B cells. Eur J Immunol 2008, 38:2106-2117

51. Ahmadi T, Flies A, Efebera Y, Sherr DH: CD40 Ligand-activated, antigenspecific $B$ cells are comparable to mature dendritic cells in presenting protein antigens and major histocompatibility complex class I- and class II-binding peptides. Immunology 2008, 124:129-140.

52. Mathieu M, Cotta-Grand N, Daudelin JF, Boulet S, Lapointe R, Labrecque N: CD40-activated $B$ cells can efficiently prime antigen-specific naive CD8+ T cells to generate effector but not memory T cells. PLoS One 2012, 7: e30139.

53. Kobayashi N, Nagumo H, Agematsu K: IL-10 enhances B-cell IgE synthesis by promoting differentiation into plasma cells, a process that is inhibited by CD27/CD70 interaction. Clin Exp Immunol 2002, 129:446-452.

54. Li MO, Wan YY, Sanjabi S, Robertson AK, Flavell RA: Transforming growth factor-beta regulation of immune responses. Annu Rev Immunol 2006, 24:99-146.

55. Huang Y, Chen X, Dikov MM, Novitskiy SV, Mosse CA, Yang L, Carbone DP: Distinct roles of VEGFR-1 and VEGFR-2 in the aberrant hematopoiesis associated with elevated levels of VEGF. Blood 2007, 110:624-631.

56. Clinchy B, Bjorck P, Paulie S, Moller G: Interleukin-10 inhibits motility in murine and human B lymphocytes. Immunology 1994, 82:376-382.

57. Parekh W, Prasad DV, Banerjee PP, Joshi BN, Kumar A, Mishra GC: B cells activated by lipopolysaccharide, but not by anti-lg and anti-CD40 antibody, induce anergy in CD8+ T cells: role of TGF-beta 1. J Immunol 2003, 170:5897-5911.

58. Patil S, Wildey GM, Brown TL, Choy L, Derynck R, Howe PH: Smad7 is induced by CD40 and protects WEHI 231 B-lymphocytes from transforming growth factor-beta -induced growth inhibition and apoptosis. J Biol Chem 2000, 275:38363-38370

doi:10.1186/1756-9966-31-47

Cite this article as: Shimabukuro-Vornhagen et al:: The immunosuppressive factors IL-10, TGF- $\beta$, and VEGF do not affect the antigen-presenting function of CD40-activated B cells. Journal of Experimental \& Clinical Cancer Research 2012 31:47.

\section{Submit your next manuscript to BioMed Central and take full advantage of:}

- Convenient online submission

- Thorough peer review

- No space constraints or color figure charges

- Immediate publication on acceptance

- Inclusion in PubMed, CAS, Scopus and Google Scholar

- Research which is freely available for redistribution 